Graphical Abstract

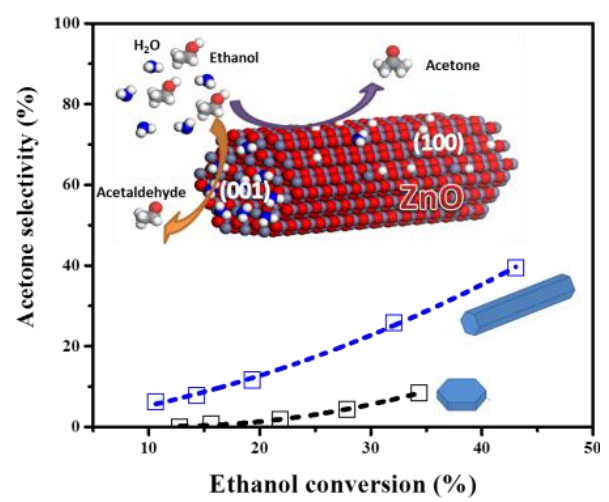




\title{
Distinct Water Activation on Polar/non-polar Facets of ZnO Nanoparticles
}

\author{
He Zhang ${ }^{\mathrm{a}}$, Junming Sun ${ }^{\mathrm{a}, *}$, Changjun Liu ${ }^{\mathrm{a}}$, and Yong Wang ${ }^{\mathrm{a}} \mathrm{b}_{*}$ \\ ${ }^{a}$ The Gene \& Linda Voiland School of Chemical Engineering and Bioengineering, Washington State \\ University, Pullman, WA 99164, USA \\ ${ }^{b}$ Institute for Integrated Catalysis, Pacific Northwest National Laboratory, Richland, WA 99352, USA \\ *E-mail: junming.sun@wsu.edu; yong.wang@pnnl.gov
}




\begin{abstract}
$\mathrm{ZnO}$ nanoparticles with differing dominant facets were prepared and characterized by a complimentary of techniques such as X-ray diffraction, electron microscopy, temperature programmed desorption of $\mathrm{H}_{2} \mathrm{O}$, and Fourier transform infrared spectroscopy analysis of adsorbed $\mathrm{D}_{2} \mathrm{O}$. For the first time, water interaction/activation is compared on $\mathrm{ZnO}$ polar and nonpolar facets. We report that non-polar facets exhibit high activity in water activation, which favors reactions such as ketonization and steam reforming in which dissociated water is involved. The distinct water dissociation on $\mathrm{ZnO}$ non-polar facets could be related to its facile formation of oxygen vacancies under realistic reaction conditions.
\end{abstract}

Key words: Facet, Water dissociation, $\mathrm{ZnO}$, ketonization, ethanol 


\section{Introduction}

A fundamental understanding of the structure-function relationship is essential in the rational design of catalysts. In addition to particle size or quantum confinement [1], morphology of catalyst particles may also influence the catalytic performances [2]. Previous studies on the facet effect of metal/metal oxide catalysts were exclusively conducted on single-crystal model surfaces with limited surface area in an ultra-high vacuum (UHV) system [3-7]. Studies on high surface area materials are limited to only a few metal oxides with controlled morphologies including $\mathrm{Co}_{3} \mathrm{O}_{4}[2,8]$, and $\mathrm{CeO}_{2}$ [9-12]. High surface area materials with well-defined morphologies are still highly desired which allow for meaningful kinetic measurement under realistic conditions without the concerns of material and pressure gaps.

Commercial fermentation of biomass produces bio-ethanol ( $20 \mathrm{wt} \%$ ethanol in water). With the increasing availability of bio-ethanol, its further conversion to value-added chemicals/fuels without unnecessary water separation is highly desired [13-15], which requires the fundamental understanding of interactions between water and the catalyst surface. $\mathrm{ZnO}$ has been widely used as a support and a promoter in alcohol conversion [14]. The effect of $\mathrm{ZnO}$ on the water activation has been studied recently in methanol steam reforming (MSR) [16-19], ethanol steam reforming (ESR) [20-22], and bio-ethanol to isobutene conversion [11, 13], etc. Although numerous studies have been reported on the unique catalytic properties of polar and non-polar facets on $\mathrm{ZnO}$ [5-7, 23], those were mainly focused on the studies in UHV using model catalysts. For example, studies on ethanol reaction over model $\mathrm{ZnO}(001) /(00-1)$ polar facets and $\mathrm{ZnO}$ (100) non-polar facets revealed that both acetaldehyde and ethylene form over $\mathrm{ZnO}$ polar facets between 410-490 $\mathrm{K}$, while ethylene is mainly produced on $\mathrm{ZnO}$ nanowires with dominant (100) non-polar facets at $517 \mathrm{~K}[5,7]$. It was also found that oxygen vacancies on both polar and non-polar facets play a 
key role in ethanol reaction [5, 7]. In photocatalysis, hexagonal plate-like $\mathrm{ZnO}$ was found to exhibit more than 5 times higher activity than rod-shaped particles in the photo-catalytic decomposition of methylene blue [24]. Recently, we synthesized stable $\mathrm{ZnO}$ nanoflakes with dominant polar facets, and investigated the influence of $\mathrm{ZnO}$ facet on MSR [16, 25]. It was found that $\mathrm{ZnO}$ with dominant polar (001) and (00-1) facets exhibited higher activity but lower $\mathrm{CO}_{2}$ selectivity, compared with commercial $\mathrm{ZnO}$ without any dominant facets in MSR [16]. In addition, even with loaded Pd, the facet exhibited significant effect on the formation of PdZn alloys and thus catalytic performances of the $\mathrm{Pd} / \mathrm{ZnO}$ catalyst in MSR [25]. Apparently, polar and non-polar facets exhibit different surface chemistries, however, the inherent mechanism is still yet to be uncovered. Herein, we prepared two $\mathrm{ZnO}$ samples: one is needle-like $\mathrm{ZnO}$ ( $\mathrm{ZnO}-$ N) with $\sim 96 \%$ (100) non-polar facets and the other is flake-like $\mathrm{ZnO}$ (ZnO-F) with $\sim 72 \%$ (001)/(00-1) polar facets. The distinct surface chemistries of the two facets were further identified and unambiguously correlated to the water activation.

\section{Materials and methods}

\subsection{Materials preparation}

$\mathrm{ZnO}$ needles were synthesized by a surfactant assisted alcohol thermal procedure according to our previous reported method [26]. In a typical synthesis, $3.0 \mathrm{~g}$ of polyvinylpyrrolidone (PVP) (Sigma-Aldrich; $\mathrm{M}=40,000$ ) were dissolved in $180 \mathrm{ml}$ of ethanol and then $0.75 \mathrm{~g}$ of zinc acetate dihydrate was slowly added into the solution. The resulting reaction mixture was stirred for several minutes, followed by the addition of $4.5 \mathrm{~g}$ of $\mathrm{NaOH}$. A turbid solution was stirred and loaded into autoclave. It was then sealed and maintained at $80{ }^{\circ} \mathrm{C}$ for $24 \mathrm{~h}$. The obtained material was washed with ethanol and distilled water for several times, respectively. The $\mathrm{ZnO}$ needle was obtained followed by calcinations at $350{ }^{\circ} \mathrm{C}$ for $3 \mathrm{hr}$. 
$\mathrm{ZnO}$ flakes were synthesized by surfactant directed crystallization according to the reported method [27] with some modifications. $2.0 \mathrm{~g}$ of Polyvinylpyrrolidone (PVP) (Sigma-Aldrich; $\mathrm{M}=40,000)$ was dissolved in $200 \mathrm{~mL}$ of pentanol, and then $8 \mathrm{ml}$ of a $0.15 \mathrm{M}$ aqueous $\mathrm{NaOH}$ solution and $6 \mathrm{ml}$ of a $0.1 \mathrm{M}$ ethanol solution of $\mathrm{Zn}\left(\mathrm{NO}_{3}\right)_{2} \cdot 6 \mathrm{H}_{2} \mathrm{O}$ were sequentially added . The reaction mixture was then kept at $90^{\circ} \mathrm{C}$ for $1 \mathrm{hr}$. The obtained material was washed with ethanol and distilled water for several times, respectively. The $\mathrm{ZnO}$ flake was obtained followed by calcinations at $350^{\circ} \mathrm{C}$ for $3 \mathrm{hr}$.

\subsection{Characterization}

X-ray diffraction (XRD) spectra were recorded using a Philips X'pert MPD (Model PW3040/00) diffractometer with a copper anode $\left(\mathrm{K} \alpha_{1}=0.15405 \mathrm{~nm}\right)$ and a scanning rate of $0.02-0.04^{\circ}$ per second between $2 \theta=20^{\circ}-70^{\circ}$. The diffraction patterns were analyzed using Jade 5 (Materials Data Inc., Livermore, CA) and the Powder Diffraction File database (International Center for Diffraction Data, Newtown Square, PA). The particle size of the ZnO crystals was estimated from the XRD patterns using the Scherrer equation $(\mathrm{d}=0.89 \lambda / B \cos \theta$, where $\lambda$ is the wavelength of $\mathrm{Cu} \mathrm{K} \alpha$ radiation, $B$ is the calibrated full width at half-maximum (FWHM) of the peak in radians, and $\theta$ is the diffraction angle of the crystal plane).

Nitrogen sorption experiments were recorded on a Micromeritics TriStar II 3020 automatic physisorption analyzer. Before adsorption analysis, samples were degassed under vacuum at 300 ${ }^{\circ} \mathrm{C}$ for $1 \mathrm{hr}$. BET surface area was calculated using the Brunauer-Emmett-Teller (BET) model.

Transmission electron microscopy (TEM) was conducted using a JEOL 2010 high-resolution analytical electron microscope operating at $200 \mathrm{kV}$ with a $\mathrm{LaB}_{6}$ filament. Scanning electron microscopy (SEM) was done on FEI SEM Quanta 200 F microscope. 
Fourier transform infrared spectrometry of $\mathrm{D}_{2} \mathrm{O}\left(\mathrm{D}_{2} \mathrm{O}-\mathrm{FTIR}\right)$, using a Bruker Tensor 27 Fourier Transform Infrared Spectrometer (FTIR) operated in the mode of in situ Diffuse Reflectance Infrared Fourier Transform spectroscopy (DRIFTS), was used to understand how water interacts with $\mathrm{ZnO}$ surfaces. Sample was loaded in the DRIFTS cell and pretreated at 400 (or 500) ${ }^{\circ} \mathrm{C}$ for $1 \mathrm{hr}$ under flowing $\mathrm{He}$ (50 SCCM). Before the $\mathrm{D}_{2} \mathrm{O}$ adsorption, the sample was cooled down to $50{ }^{\circ} \mathrm{C}$ in $\mathrm{He}(50 \mathrm{SCCM})$ where the background was taken. $\mathrm{D}_{2} \mathrm{O}$ adsorption was accomplished by flowing $\mathrm{D}_{2} \mathrm{O} /$ helium gas through the catalyst samples at $50^{\circ} \mathrm{C}$ until the saturation of the catalyst surface was achieved, monitored by TCD. The $\mathrm{D}_{2} \mathrm{O}$ /helium was generated by flowing $\mathrm{He}(20$ SCCM) through a bubble generator. The absorbance spectra were recorded at $50{ }^{\circ} \mathrm{C}$ after heating sample at different temperatures $\left(50{ }^{\circ} \mathrm{C}, 150{ }^{\circ} \mathrm{C}, 250{ }^{\circ} \mathrm{C}, 350{ }^{\circ} \mathrm{C}, 400{ }^{\circ} \mathrm{C}\right)$ for 30 minutes under helium (50 SCCM).

Temperature programmed desorption (TPD) of water was recorded in an AutoChem II 2920 chemisorption analyzer with a vapor generator. Typically, 50-100 mg catalyst were packed by quartz wool in U-shaped tubes. Catalyst samples were pretreated under Helium at $400{ }^{\circ} \mathrm{C}$ for 1 hr, and then cooled down to $50{ }^{\circ} \mathrm{C}$ for the saturation of water vapor. After desorbing weekly adsorbed water with Helium at $50{ }^{\circ} \mathrm{C}$, the temperature was ramped to $600{ }^{\circ} \mathrm{C}$ with a rate of 10 ${ }^{\circ} \mathrm{C} /$ min under Helium. MS signals $(\mathrm{m} / \mathrm{z}=16,17$ and 18$)$ were recorded by ThermoStars 200 AMU mass spectrometer.

\subsection{Catalytic reaction}

Bio-ethanol conversion reactions were conducted in a fixed-bed stainless steel reactor (i.d. 5 $\mathrm{mm}$ ), which has been described elsewhere [13]. Typically, 50 to $100 \mathrm{mg}$ of catalyst was packed and sandwiched by quartz wool beds. The thermocouple was placed in the middle of the catalyst bed to monitor the reaction temperature. Before the reaction, catalysts were firstly pre-treated in 
$\mathrm{N}_{2}(50 \mathrm{ml} / \mathrm{min})$ at $400{ }^{\circ} \mathrm{C}$ (ramping rate was $5{ }^{\circ} \mathrm{C} / \mathrm{min}$ ) for 1 hour. Then a mixture of $\mathrm{H}_{2} \mathrm{O} / \mathrm{ethanol}$ (or $\mathrm{H}_{2} \mathrm{O} /$ acetaldehyde) (a 10:1 molar ratio) was introduced into the evaporator $\left(180{ }^{\circ} \mathrm{C}\right.$ ) by a syringe pump and carried into the reactor by flowing nitrogen gas ( $4.24 \%$ ethanol). The product line was heated to $150{ }^{\circ} \mathrm{C}$ before a cold trap to avoid the condensation of liquid products.

\section{Results and discussion}

Fig. $1 \mathrm{a}$ and $1 \mathrm{~b}$ show the TEM images of $\mathrm{ZnO}-\mathrm{N}$ and $\mathrm{ZnO}-\mathrm{F}$. $\mathrm{ZnO}-\mathrm{N}$ displays a needle-like morphology with 50-200 nanometers in length and 10-20 nanometers in width (Fig.S1a and S1).

On the other hand, ZnO-F displays a flake-like morphology, 200-400 nm in width and tens of nanometers in thickness (Fig. 1c). XRD patterns for both $\mathrm{ZnO}-\mathrm{N}$ and $\mathrm{ZnO}-\mathrm{F}$ samples display Wurtzite structure (Fig. S2). It is noteworthy that the peaks characteristic of (100) and (101) on ZnO-N are significantly broadened (Fig. S2), suggesting the nano-scale dimensions along [100] and [101] and the dominant non-polar facets (Fig. S3). According to the Scherer equation, the calculated dimensions for $\mathrm{ZnO}-\mathrm{N}$ are $17 \mathrm{~nm}, 48 \mathrm{~nm}$, and $16 \mathrm{~nm}$, corresponding to the crystal diameter normal to (100), (002) and (101). It suggests that the particles are elongated along [001] such that the polar $\mathrm{ZnO}$ surfaces are located at the tips of the $\mathrm{ZnO}$ needles (Fig. S3), consistent with our previous results [25]. In contrast, ZnO-F shows the average dimensions of $79 \mathrm{~nm}, 59$ $\mathrm{nm}$, and $69 \mathrm{~nm}$ perpendicular to (100), (002) and (101) planes of $\mathrm{ZnO}$, indicating that $(001) /(00-$ 1) polar planes are dominant on $\mathrm{ZnO}-\mathrm{F}$, which can be further evidenced by TEM observation (Fig. 1b-1d). Based on the dimensions from the TEM images of the two types of $\mathrm{ZnO}$ particles, the fraction of different facets were calculated and the results are summarized in Table S1. XRD results and TEM images of two spent samples suggest that dominant planes are still maintained even after bio-ethanol reactions at $400{ }^{\circ} \mathrm{C}$ although the overall dimensions increased (Fig. S2, S4 and S5). It should be noted that dominant facets of $\mathrm{ZnO}$ are maintained under the conditions 
studied, suggesting that the $\mathrm{ZnO}-\mathrm{N}$ and $\mathrm{ZnO}-\mathrm{F}$ materials are hydrothermally/thermally stable under these conditions, which is pivotal to study the effects of $\mathrm{ZnO}$ facet on bio-ethanol conversion.

The water interaction and identification of $\mathrm{OH}$ bands on different facets of $\mathrm{ZnO}$ has been previously studied in $\mathrm{UHV}$ using both $\mathrm{ZnO}$ single crystal and $\mathrm{ZnO}$ nanoparticles [28]. The band at $3620 \mathrm{~cm}^{-1}$ is attributed to the $\mathrm{OH}$ on the polar $\mathrm{O}-\mathrm{ZnO}(00-1)$ surface formed via dissociation of water on oxygen vacancy sites, while partially dissociated water on the mixed-terminated $\mathrm{ZnO}$ (100) surface yields both $\mathrm{OH}$ species with coadsorbed $\mathrm{H}_{2} \mathrm{O}$ at $3672 \mathrm{~cm}^{-1}$ and the coexistent $\mathrm{H}_{2} \mathrm{O}$ at $\sim 3150$ and $3687 \mathrm{~cm}^{-1}$. The bands at 3639 and $3656 \mathrm{~cm}^{-1}$ represent isolated $\mathrm{OH}$ species formed on the mixed-terminated $\mathrm{ZnO}$ (100) surface, and interaction of water with oxygen defects forms $\mathrm{O}-\mathrm{H}^{\cdots} \mathrm{O}$ species at 3564 and $3448 \mathrm{~cm}^{-1}$ [28].

To investigate the effect of facet on the water activation and understand the nature of surface hydroxyl groups under realistic conditions, temperature programmed $\mathrm{D}_{2} \mathrm{O}$-FTIR was conducted on $\mathrm{ZnO}-\mathrm{N}$ (Fig. 2A) and ZnO-F (Fig. 2B). The isotopic shift in $\mathrm{D}_{2} \mathrm{O}-\mathrm{FTIR}$ was used to unambiguously identify the hydroxyl groups on $\mathrm{ZnO}$. Particularly, over the $\mathrm{ZnO}-\mathrm{F}$ (Fig. 2B), a broad hump from 3750 to $3150 \mathrm{~cm}^{-1}$ (where $\mathrm{OH}$ groups were also identified) was observed. For comparison purposes, we also studied $\mathrm{D}_{2} \mathrm{O}$-FTIR on a commercial $\mathrm{ZnO}$ (ZnO-P) without any dominant facets (Fig. S6) and results are shown in Fig. 2C. Over ZnO-N pretreated under Helium at $400{ }^{\circ} \mathrm{C}$, hydroxyl $(\mathrm{OH})$ groups on both $\mathrm{ZnO}$ polar $\left(3618 \mathrm{~cm}^{-1}\right)$ and non-polar facets $\left(3677 \mathrm{~cm}^{-1}\right)$ were observed. Isolated $\mathrm{OH}$ groups on $\mathrm{ZnO}$ non-polar facets $\left(3656 \mathrm{~cm}^{-1}\right)$ and $\mathrm{O}-\mathrm{H}^{\cdots} \mathrm{O}$ species (3565 and $3450 \mathrm{~cm}^{-1}$ ) created via $\mathrm{H}_{2} \mathrm{O}$ interaction with structural defects were also resolved. In addition, a weak narrow band at $3718 \mathrm{~cm}^{-1}$ is detected on $\mathrm{ZnO}-\mathrm{N}$ only, which could be related to the non-H-bonded $\mathrm{OH}$ groups of a water molecule [28], adsorbed on the (100) nonpolar facet. 
Interestingly, the expected dominant OH hydroxyl groups detected on polar facets in UHV [28] was not observed in this study. Instead, only very weak hydroxyl bands at $3679,3662,3639$, and $3614 \mathrm{~cm}^{-1}$ are resolved on $\mathrm{ZnO}-\mathrm{F}$ with dominant $(001) /(00-1)$ polar facets. Meanwhile, a broad hump between $3100 \mathrm{~cm}^{-1}$ and $3600 \mathrm{~cm}^{-1}$ is observed, which can be attributed to the H-bonded hydroxyl of molecularly adsorbed $\mathrm{H}_{2} \mathrm{O}$. Over $\mathrm{ZnO}-\mathrm{P}$, bands corresponding to both $\mathrm{OH}$ groups on both non-polar facet and polar facets are observed (Fig. 2C), similar to those on $\mathrm{ZnO}-\mathrm{N}$. However, non-H-bonded $\mathrm{OH}$ at $3718 \mathrm{~cm}^{-1}$ is not detected on $\mathrm{ZnO}-\mathrm{P}$, and the intensity of $\mathrm{O}-\mathrm{H}^{\cdots} \mathrm{O}$ species (3558 and $3446 \mathrm{~cm}^{-1}$ ) is relatively lower than that of $\mathrm{ZnO}-\mathrm{N}$, likely due to the lower portion of (100) polar facet/oxygen defect on ZnO-P. More importantly, the H-bonded hydroxyl of molecular $\mathrm{H}_{2} \mathrm{O}$ on polar facet is also observed as evidenced by the broad peak between 3100 $\mathrm{cm}^{-1}$ and $3350 \mathrm{~cm}^{-1}$. The results reveal that, under realistic conditions, the $\mathrm{ZnO}$ hydroxyl groups observed in this study are generated from water dissociation on non-polar facets and possibly structural defects, while molecularly adsorbed $\mathrm{H}_{2} \mathrm{O}$ might dominate on $\mathrm{ZnO}$ polar facets.

After saturating the samples with $\mathrm{D}_{2} \mathrm{O}$ at $50{ }^{\circ} \mathrm{C}$, desorption spectra of $\mathrm{D}_{2} \mathrm{O}$ at different temperatures are obtained. As can be seen in Fig. 2A (red curve), over the $\mathrm{ZnO}-\mathrm{N}$, bands associated with $\mathrm{OH}$ groups $\left(3718,3656,3565\right.$, and $\left.3450 \mathrm{~cm}^{-1}\right)$ decrease. Meanwhile a similar pattern of new bands associated with deuteroxyl groups (2740, 2711, 2698, 2667, 2632, and 2557 $\left.\mathrm{cm}^{-1}\right)$ is detected at $50{ }^{\circ} \mathrm{C}$, evidenced by the isotopic ratios of $v(\mathrm{OH}): \mathrm{v}(\mathrm{OD})$ of 1.35 . The band at $2711 \mathrm{~cm}^{-1}$ corresponds to the OD group on $\mathrm{ZnO}$ (100) non-polar facets, and the one at $2667 \mathrm{~cm}^{-1}$ is related to the adsorption of $\mathrm{OD}$ on $\mathrm{ZnO}$ polar facets. The bands at $2740 \mathrm{~cm}^{-1}$ and $2698 \mathrm{~cm}^{-1}$ are attributed to isolated $\mathrm{OD}$ related to $\mathrm{ZnO}$ non-polar facets, and the broad bands at $2632 \mathrm{~cm}^{-1}$ and $2557 \mathrm{~cm}^{-1}$ correspond to $\mathrm{O}-\mathrm{D} \cdots \mathrm{O}$ species. Upon increasing desorption temperature up to 400 ${ }^{\circ} \mathrm{C}$, the intensity of bands associated with both $\mathrm{OH}$ and $\mathrm{OD}$ barely changes. It is clear that the 
water dissociation/H-D exchange reactions occur at $50{ }^{\circ} \mathrm{C}$, suggesting the high activity of $\mathrm{ZnO}$ (100) non-polar facets. On the contrary, no band can be resolved in OD region on the ZnO-F regardless of desorption temperature, or even after a pretreatment in $\mathrm{D}_{2} \mathrm{O}$ vapor at $450{ }^{\circ} \mathrm{C}$ (Fig. 2B, black curve). The broad peak between $3100 \mathrm{~cm}^{-1}$ and $3600 \mathrm{~cm}^{-1}$ also show negligible changes. It further confirms that the polar facet of $\mathrm{ZnO}-\mathrm{F}$ shows low/no activity for water dissociation. It should be mentioned that $\sim 28 \%$ of (100) non-polar facets present on $\mathrm{ZnO}-\mathrm{F}$ (Table S1). The fact that no OD groups associated with non-polar facet are observed could be due to the low population of the OD groups registering below the detection limit of FTIR. It is still unclear why $\mathrm{OH}$ groups are present on the polar facet $\left(3620 \mathrm{~cm}^{-1}\right)$, and there is H-D exchange (shown at $2667 \mathrm{~cm}^{-1}$ ) on the $\mathrm{ZnO}-\mathrm{F}$ (Figure 2A). We speculate that a substantial amount of defects might exist on the polar facet of $\mathrm{ZnO}-\mathrm{F}$, due to the small dimension of [100] (i.e., $17 \mathrm{~nm}$ ). The presence of those defects could promote water dissociation, leading to the formation of $\mathrm{OH}$ groups.

Over the ZnO-P, bands associated with $\mathrm{OH}$ groups $\left(3679,3662,3620,3556\right.$, and $\left.3448 \mathrm{~cm}^{-1}\right)$ decreases, and new bands associated with deuteroxyl groups appear at 2706, 2669, 2628, and $2553 \mathrm{~cm}^{-1}$. Different from $\mathrm{ZnO}-\mathrm{N}$, as desorption temperature increases, the intensity of the deuteroxyls also increases (Fig. 2C), indicating its relatively lower activity for $\mathrm{D}_{2} \mathrm{O}$ dissociation/H-D exchange. However, the broad hump between $3100 \mathrm{~cm}^{-1}$ and $3350 \mathrm{~cm}^{-1}$ still remains unchanged, further confirming the low/lack of activity of $(001) /(00-1)$ polar facets on $\mathrm{ZnO}-\mathrm{P}$. To summarize, although the question regarding the interpretation of the band at $\sim 3620$ $\mathrm{cm}^{-1}$ (OH on the polar facet) is still open to discussion, our FTIR results clearly indicate that dissociative adsorption of $\mathrm{H}_{2} \mathrm{O}$ is favorable on $\mathrm{ZnO}$ (100) non-polar facets, while molecularly 
adsorbed molecular water prevails on the $\mathrm{ZnO}(001) /(00-1)$ polar facets over the $\mathrm{ZnO}$ powder samples.

The formation and thermal stability of hydroxyl groups on $\mathrm{ZnO}$ has been widely studied to differentiate the surface structure and chemistry of (00-1) polar and (100) non-polar facet in UHV. No OH bands were observed on (100) non-polar and (001)/(00-1) polar facets of $\mathrm{ZnO}$ single crystal, but oxygen vacancies were noted. Upon exposure to water, water dissociation took place on the oxygen vacancies, leading to the observation of surface hydroxyl groups. Thermal stability of hydroxyl groups evidenced by temperature programmed desorption (TPD) reveal that recombinative desorption of hydroxyl groups on (100) surface occurs at temperatures as low as $300{ }^{\circ} \mathrm{C}$, while those on O-terminated (00-1) surface are stable up to more than $500{ }^{\circ} \mathrm{C}[28,29]$. Consistent with this observation, our $\mathrm{H}_{2} \mathrm{O}-\mathrm{TPD}$ experiments (Fig. 3) reveal that the $\mathrm{H}_{2} \mathrm{O}$ desorption peak temperature of $\mathrm{ZnO}-\mathrm{F}$ is much higher than that of $\mathrm{ZnO}-\mathrm{N}\left(\sim 520{ }^{\circ} \mathrm{C}\right.$ versus $\sim 420$ $\left.{ }^{\circ} \mathrm{C}\right)$. Different from the observations in UHV [28], FTIR characterizations only show a broad hump with poor resolved hydroxyl peaks on $\mathrm{ZnO}-\mathrm{F}$ with dominant (001)/(00-1) polar facet (Fig. 2B). Further $\mathrm{D}_{2} \mathrm{O}$-FTIR experiments at an increased temperature (i.e, $400{ }^{\circ} \mathrm{C}$ ) also revealed no water dissociation/H-D exchange reactions (Fig. 2B). The question of the $\mathrm{H}_{2} \mathrm{O}$ desorption observed at high-temperature $\left(>500{ }^{\circ} \mathrm{C}\right.$ ) by $\mathrm{H}_{2} \mathrm{O}$-TPD (Fig. 3) is thus open to the further discussion. While it is unclear why water dissociation was not observed on $\mathrm{ZnO}-\mathrm{F}$ contradictory to what was observed in UHV, the surface reconstruction and formation of oxygen vacancy must be vital to the water dissociation on the powder $\mathrm{ZnO}$. We propose that the ability to form oxygen vacancy on the $\mathrm{ZnO}$ polar facet is much harder than that on $\mathrm{ZnO}$ non-polar facet under realistic conditions. Indeed, our $\mathrm{H}_{2} \mathrm{O}-\mathrm{FTIR}$ reveals that oxygen vacancy on $\mathrm{ZnO}-\mathrm{N}$ is much more pronounced than that on $\mathrm{ZnO}-\mathrm{F}$, evidenced by the bands at 3558 and $3446 \mathrm{~cm}^{-1}$ shown in Figure 
2A \& 2B.. However, a high temperature (i.e., $400{ }^{\circ} \mathrm{C}$ ) pretreatment in flowing hydrogen for $12 \mathrm{~h}$ is required to create the oxygen vacancy on $\mathrm{ZnO}-\mathrm{F}$ with dominant polar facets [16]. The current results suggest that while activation using $\mathrm{H}_{2}$ is required to generate the oxygen vacancy over $\mathrm{ZnO}$ polar facets, $\mathrm{ZnO}$ with dominant non-polar facet could favor the formation of oxygen vacancy and thus reactions involving water activation under realistic conditions.

Water has been found to play essential roles in the bio-ethanol-to-acetone conversion[11, 13, 15], and the water activation on the base or balanced acid-base pairs is believed to be essential to enhance the oxidation of acetaldehyde to form acetone via a possible ketonization pathway [15]. To further verify the distinct activity of water activation observed on the $\mathrm{ZnO}$ polar and nonpolar facets, bio-ethanol conversion was performed on the $\mathrm{ZnO}-\mathrm{N}$ and $\mathrm{ZnO}-\mathrm{F}$ catalysts. Fig. 4 shows the evolution of products with bio-ethanol conversion. Dehydration reaction takes place on both catalysts. However, it plays a minor role in the overall reaction as evidenced by the low ethylene selectivity $(<8 \%)$, consistent with our previous observation [13]. On the contrary, dehydrogenation was found to be the dominant reaction pathway, evidenced by the primary formation of acetaldehyde at low conversion. Kinetic analysis reveals that the ethanol conversion rate on the $\mathrm{ZnO}-\mathrm{F}$ is almost two times higher than that on the $\mathrm{ZnO}-\mathrm{N}$ (Table 1). This observation indicates that the dehydrogenation of ethanol to acetaldehyde could occur on both $\mathrm{ZnO}$ $(001) /(00-1)$ polar facets and $\mathrm{ZnO}(100)$ non-polar facets, however $\mathrm{ZnO}(001) /(00-1)$ polar facet is more active than $\mathrm{ZnO}$ (100) non-polar facet, which is consistent with our previous report [16]. As ethanol conversion increases, acetone selectivity increases at the expense of acetaldehyde, suggesting that acetone is a secondary product formed from acetaldehyde. Moreover, the bioethanol to acetone reaction is limited by acetaldehyde conversion. Crotonaldehyde was also observed. However, different from those studies using high purity ethanol as a feed [15], 
crotonaldehyde selectivity is less than $1 \%$ for both catalysts in the current bio-ethanol (20 wt $\%$ ethanol in $\mathrm{H}_{2} \mathrm{O}$ ) reaction. Apparently, the acetaldehyde to acetone conversion is favored in the presence of water [15] due to the acetaldehyde oxidation by dissociated water.

Considering the different surface areas and the dependence of the acetone selectivity on ethanol conversion, product selectivity (i.e., acetaldehyde and acetone) is compared at same ethanol conversion by adjusting the space velocity (Fig. 4). Interestingly, acetone selectivity on $\mathrm{ZnO}-\mathrm{N}$ with dominant (100) non-polar facets is always higher than that on $\mathrm{ZnO}-\mathrm{F}$ with dominant (001)/(00-1) polar ones. This result agrees well with the favorite water dissociation on (100) facets evidenced by $\mathrm{D}_{2} \mathrm{O}-\mathrm{FTIR}$, as well as a much higher surface area of (100) non-polar facets on $\mathrm{ZnO}-\mathrm{N}$ compared to on $\mathrm{ZnO}-\mathrm{F}\left(\sim 35 \mathrm{~m}^{2} / \mathrm{g}\right.$ vs $1.4 \mathrm{~m}^{2} / \mathrm{g}$, Table $\left.\mathrm{S} 1\right)$. Further kinetic analysis shows that the acetone formation rate on $\mathrm{ZnO}-\mathrm{N}$ normalized by total surface area is more than three times higher than that of $\mathrm{ZnO}-\mathrm{F}$ (Table 1). However, the acetone formation rate normalized by the surface area of (100) non-polar facets are comparable on both $\mathrm{ZnO}-\mathrm{N}$ and $\mathrm{ZnO}-\mathrm{F}$ catalysts (7.31 vs $8.31, \times 10^{-5}$ mol acetone. $\left.\mathrm{s}^{-1} \cdot \mathrm{m}_{(100)}\right)^{-2}$, Table 1 and $\left.\mathrm{S} 1\right)$. Moreover, the apparent activation energy for acetaldehyde to acetone conversion on the two catalysts is similar (145 vs 152 $\mathrm{kJ} / \mathrm{mol}$ ). These results further suggest that acetaldehyde to acetone conversion is limited by water activation on $\mathrm{ZnO}(100)$ non-polar facets, and that $\mathrm{ZnO}(001) /(00-1)$ polar facets do not seem to be involved in the water dissociation.

\section{Conclusions}

In summary, we found that the water activation/dissociation occurs mainly on oxygen vacancy of the $\mathrm{ZnO}$ powder samples. Under realistic conditions, the formation of oxygen vacancies on (100) non-polar facets is much more facile than on the $\mathrm{ZnO}(001) /(00-1)$ polar facets. Both FTIR and $\mathrm{H}_{2} \mathrm{O}$-TPD suggest that $\mathrm{H}_{2} \mathrm{O}$ might be strongly adsorbed on $\mathrm{ZnO}(001) /(00-1)$ polar facets, 
which inhibits the formation of the oxygen vacancy and thus adsorption/dissociation of $\mathrm{H}_{2} \mathrm{O}$ on the $\mathrm{ZnO}-\mathrm{F}$. In the bio-ethanol reactions, both the $\mathrm{ZnO}$ (100) non-polar facet and the $\mathrm{ZnO}$ $(001) /(00-1)$ polar facets are active for ethanol dehydrogenation to from acetaldehyde. However, the subsequent acetaldehyde reaction to form acetone via the ketonization pathway mainly occurs on the $\mathrm{ZnO}$ (100) non-polar facet on which water dissociation is highly favored. The current work provides a fundamental understanding of $\mathrm{H}_{2} \mathrm{O}$ dissociation as affected by the facet of the metal oxide catalyst, and consequently its relations with the water consuming reactions, such as ketonization and steam reforming.

\section{Acknowledgments}

We greatly acknowledge the financial support by the U.S. Department of Energy (grant No. DE-FG02-05ER15712). Part of the research was performed at Environmental Molecular Sciences Laboratory (EMSL), a national scientific user facility sponsored by the Department of Energy's Office of Biological and Environmental Research and located at Pacific Northwest National Laboratory (PNNL). We thank the Franceschi Microscopy and Imaging Center (FMIC) at Washington State University for the access to SEM. J. Sun thanks Dr. Chongmin Wang (PNNL) and Dr. Renqin Zhang (WSU) for the helpful discussions.

\section{Supplementary material}

Supplementary data associated with this article can be found in the online version.

\section{References}

[1] C.-K. Tsung, J.N. Kuhn, W. Huang, C. Aliaga, L.-I. Hung, G.A. Somorjai, P. Yang, J. Am. Chem. Soc., 131 (2009) 5816-5822.

[2] Y. Li, W.J. Shen, Chem. Soc. Rev., 43 (2014) 1543-1574.

[3] G. Ertl, Catal. Rev. - Sci. Eng., 21 (1980) 201-223.

[4] N.D. Spencer, R.C. Schoonmaker, G.A. Somorjai, J. Catal., 74 (1982) 129-135. 
[5] G. Kwak, K.J. Yong, J. Phys. Chem. C, 112 (2008) 3036-3041.

[6] M.P. Hyman, V.M. Lebarbier, Y. Wang, A.K. Datye, J.A. Vohs, J. Phys. Chem. C, 113 (2009) 7251-7259.

[7] E. Martono, M.P. Hyman, J.M. Vohs, Phys. Chem. Chem. Phys., 13 (2011) 9880-9886.

[8] X. Xie, Y. Li, Z.-Q. Liu, M. Haruta, W. Shen, Nature, 458 (2009) 746-749.

[9] Z.L. Wu, M.J. Li, D.R. Mullins, S.H. Overbury, Acs Catal., 2 (2012) 2224-2234.

[10] Z.L. Wu, M.J. Li, S.H. Overbury, ChemCatChem, 4 (2012) 1653-1661.

[11] C.J. Liu, J.M. Sun, C. Smith, Y. Wang, Appl. Catal., A, 467 (2013) 91-97.

[12] Y. Li, Z. Wei, F. Gao, L. Kovarik, C.H.F. Peden, Y. Wang, J. Catal., 315 (2014) 15-24.

[13] J.M. Sun, K.K. Zhu, F. Gao, C.M. Wang, J. Liu, C.H.F. Peden, Y. Wang, J. Am. Chem. Soc., 133 (2011) 1109611099 .

[14] S.D. Davidson, H. Zhang, J. Sun, Y. Wang, Dalton Trans., (2014).

[15] J. Sun, Y. Wang, Acs Catal., (2014) 1078-1090.

[16] B. Halevi, S. Lin, A. Roy, H. Zhang, E. Jeroro, J. Vohs, Y. Wang, H. Guo, A.K. Datye, J. Phys. Chem. C, 117 (2013) 6493-6503.

[17] N. Iwasa, S. Masuda, N. Ogawa, N. Takezawa, Appl. Catal., A, 125 (1995) 145-157.

[18] S. Sa, H. Silva, L. Brandao, J.M. Sousa, A. Mendes, Appl. Catal., B, 99 (2010) 43-57.

[19] M. Friedrich, S. Penner, M. Heggen, M. Armbruster, Angew. Chem., Int. Ed., 52 (2013) 4389-4392.

[20] S. Davidson, J.M. Sun, Y. Wang, Top. Catal., 56 (2013) 1651-1659.

[21] M. Ni, D.Y.C. Leung, M.K.H. Leung, Int. J. Hydrog. Energy, 32 (2007) 3238-3247.

[22] V.M. Lebarbier, A.M. Karim, M.H. Engelhard, Y. Wu, B.Q. Xu, E.J. Petersen, A.K. Datye, Y. Wang, ChemSusChem, 4 (2011) 1679-1684.

[23] G.R. Li, T. Hu, G.L. Pan, T.Y. Yan, X.P. Gao, H.Y. Zhu, J. Phys. Chem. C, 112 (2008) 11859-11864.

[24] A. McLaren, T. Valdes-Solis, G. Li, S.C. Tsang, J. Am. Chem. Soc., 131 (2009) 12540-12541.

[25] H. Zhang, J. Sun, V.L. Dagle, B. Halevi, A.K. Datye, Y. Wang, Acs Catal., 4 (2014) 2379-2386.

[26] C.L. Wang, E.H. Shen, E.B. Wang, L. Gao, Z.K. Kang, C.G. Tian, Y. Lan, C. Zhang, Mater. Lett., 59 (2005) 2867-2871.

[27] J.H. Zhang, H.Y. Liu, Z.L. Wang, N.B. Ming, Z.R. Li, A.S. Biris, Adv. Funct. Mater., 17 (2007) 3897-3905.

[28] H. Noei, H.S. Qiu, Y.M. Wang, E. Loffler, C. Woll, M. Muhler, Phys. Chem. Chem. Phys., 10 (2008) $7092-$ 7097.

[29] Y. Wang, M. Muhler, C. Woll, Phys. Chem. Chem. Phys., 8 (2006) 1521-1524. 
Fig. 1. TEM/SEM images of $\mathrm{ZnO}$ catalysts: a) $\mathrm{ZnO}$ needle; b-d) $\mathrm{ZnO}$ flake.

Fig. 2. $\mathrm{D}_{2} \mathrm{O}-\mathrm{FTIR}$ on $\mathrm{ZnO}-\mathrm{N}(\mathrm{A}), \mathrm{ZnO}-\mathrm{F}(\mathrm{B})$ and $\mathrm{ZnO}-\mathrm{P}(\mathrm{C})$.

Fig. 3. $\mathrm{H}_{2} \mathrm{O}-\mathrm{TPD}(\mathrm{m} / \mathrm{z}=17)$ over $\mathrm{ZnO}$ flake $(\mathrm{ZnO}-\mathrm{F})$ and needle $(\mathrm{ZnO}-\mathrm{N})$.

Fig. 4. Product selectivity as a function of ethanol conversion over $\mathrm{ZnO}$ flake ( $\mathrm{ZnO}-\mathrm{F})$ and needle $(\mathrm{ZnO}-\mathrm{N})$ catalysts. 

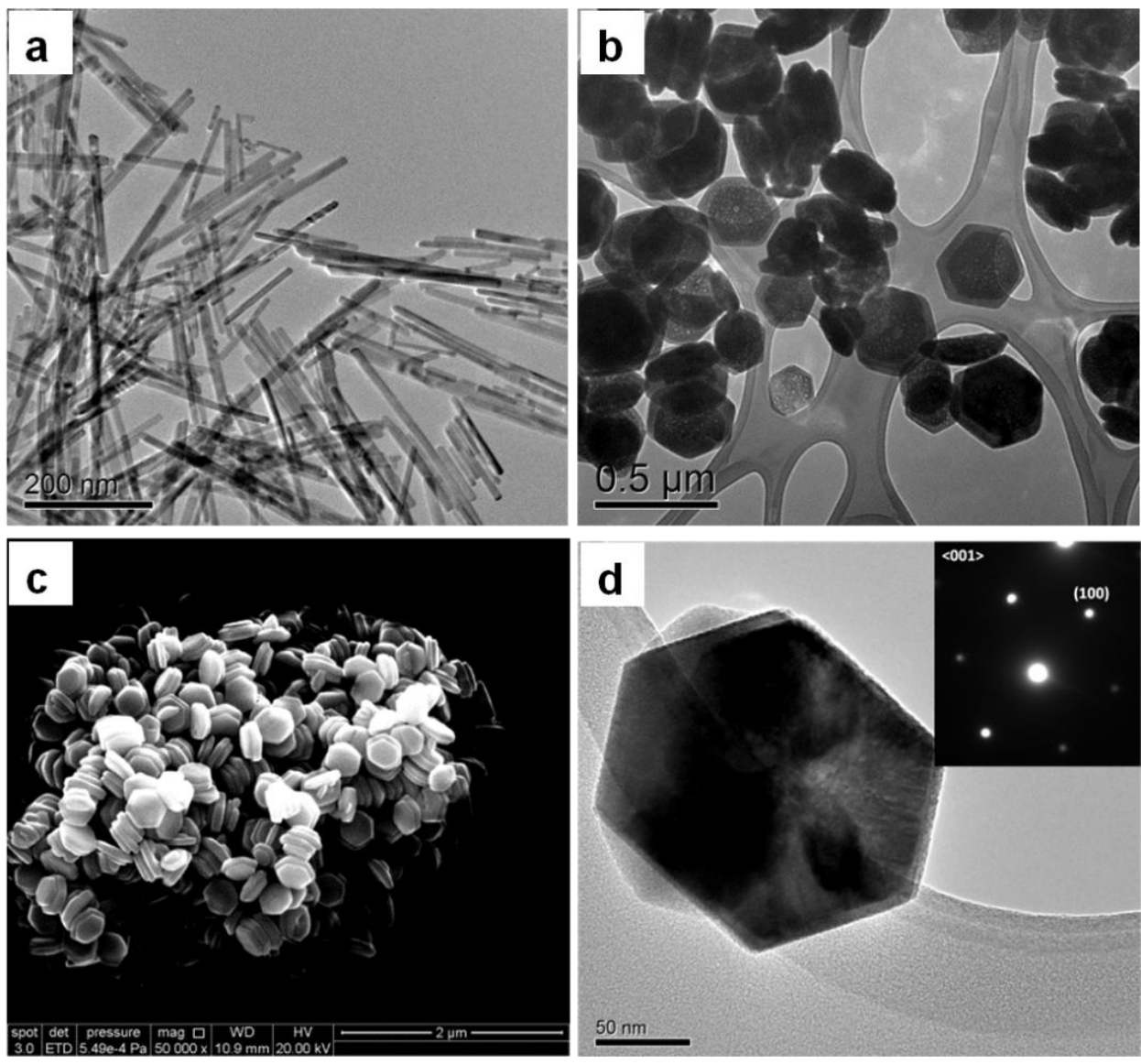

Fig. 1. TEM/SEM images of $\mathrm{ZnO}$ catalysts: a) $\mathrm{ZnO}$ needle; b-d) $\mathrm{ZnO}$ flake.

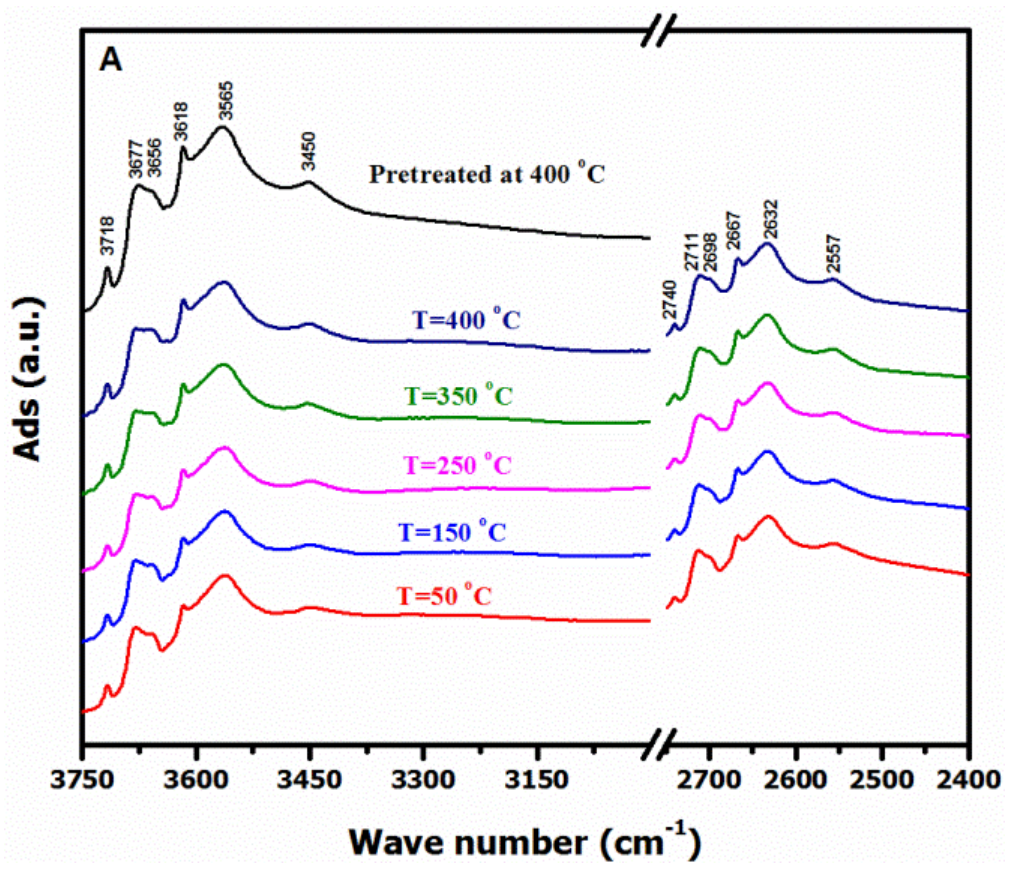



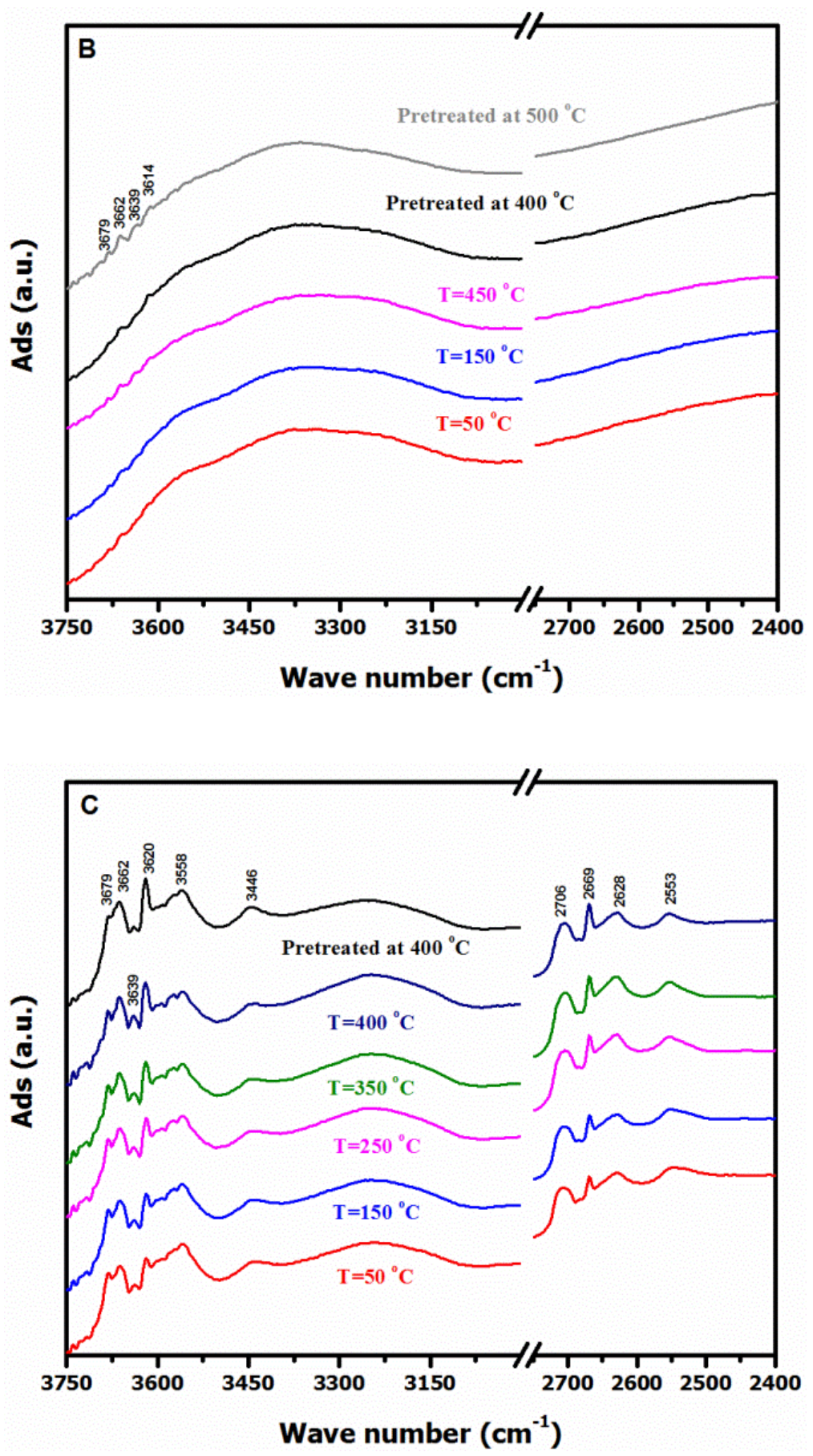

Fig. 2. $\mathrm{D}_{2} \mathrm{O}-\mathrm{FTIR}$ on $\mathrm{ZnO}-\mathrm{N}(\mathrm{A}), \mathrm{ZnO}-\mathrm{F}(\mathrm{B})$ and $\mathrm{ZnO}-\mathrm{P}(\mathrm{C})$. 


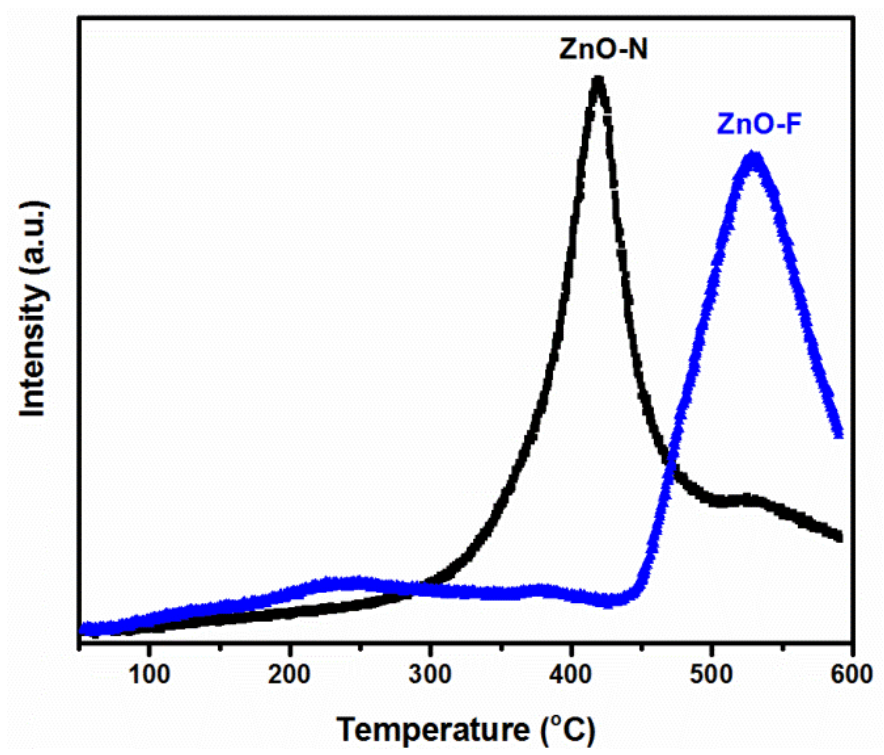

Fig. 3. $\mathrm{H}_{2} \mathrm{O}-\mathrm{TPD}(\mathrm{m} / \mathrm{z}=17)$ over $\mathrm{ZnO}$ flake $(\mathrm{ZnO}-\mathrm{F})$ and needle $(\mathrm{ZnO}-\mathrm{N})$. 


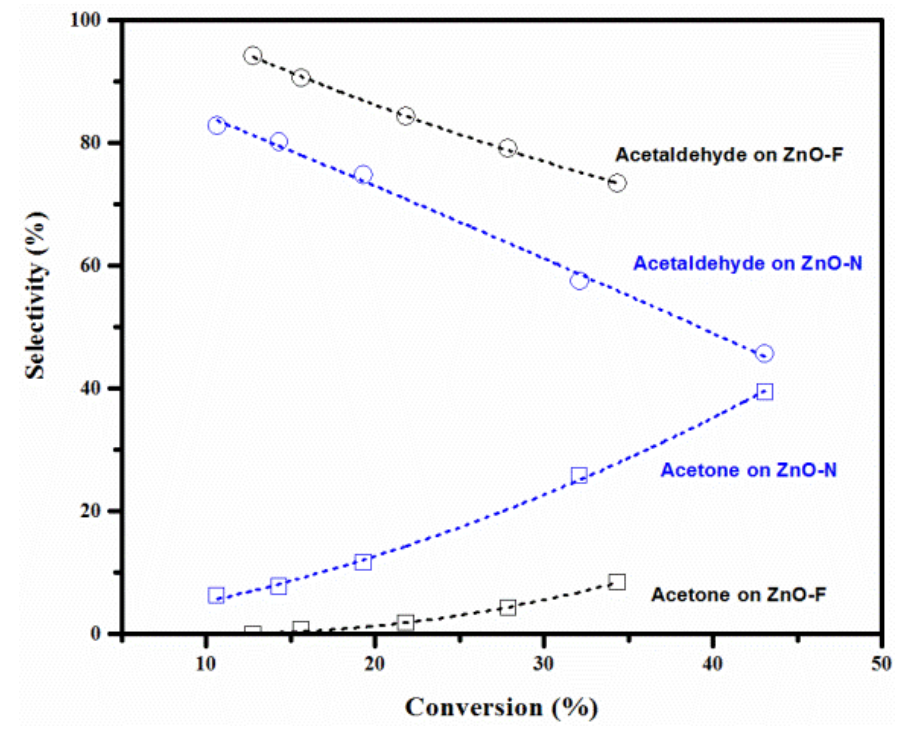

Fig. 4. Product selectivity as a function of ethanol conversion over $\mathrm{ZnO}$ flake ( $\mathrm{ZnO}-\mathrm{F})$ and needle $(\mathrm{ZnO}-\mathrm{N})$ catalysts.

Table 1. Activity comparison of $\mathrm{ZnO}$ needle and flake for catalytic bio-ethanol conversion

\begin{tabular}{|c|c|c|c|c|c|c|c|}
\hline Catalysts & $\begin{array}{l}\text { Surface area } \\
\left(\mathrm{m}^{2} / \mathrm{g}\right)\end{array}$ & $\begin{array}{l}\text { Ethanol } \\
\text { Con. }(\%)\end{array}$ & $\begin{array}{l}\text { Acetaldehyde } \\
\text { Sel. }(\%)\end{array}$ & $\begin{array}{l}\text { Acetone Sel. } \\
(\%)\end{array}$ & $\begin{array}{l}\text { Ethanol rate } \\
\left(\mathrm{mol}^{\mathrm{a}} \mathrm{s}^{-1} \cdot \mathrm{m}^{-2}\right)\end{array}$ & $\begin{array}{l}\text { Acetone rate } \\
\left(\mathrm{mol}^{\mathrm{a}} \mathrm{s}^{-1} \cdot \mathrm{m}^{-2}\right)\end{array}$ & $\begin{array}{l}\text { Acetone rate } \\
\left.\left(\mathrm{mol}^{\mathrm{b}} \mathrm{s}^{-1} \cdot \mathrm{m}_{(100)}\right)^{-2}\right)\end{array}$ \\
\hline $\mathrm{ZnO}-\mathrm{N}$ & 36 & 19.3 & 74.8 & 11.7 & $9.00 \mathrm{e}-4$ & $7.01 e-5$ & $7.31 e-5$ \\
\hline $\mathrm{ZnO}-\mathrm{F}$ & 5 & 21.8 & 84.3 & 1.9 & $1.83 \mathrm{e}-3$ & $2.32 \mathrm{e}-5$ & $8.28 \mathrm{e}-5$ \\
\hline
\end{tabular}

10:1 molar $\mathrm{H}_{2} \mathrm{O} /$ ethanol, $4.24 \%$ ethanol, $\mathrm{T}=400{ }^{\circ} \mathrm{C}$. a, rate normalized by total surface area; $\mathrm{b}$, rate normalized by surface area of non-polar facet 